\title{
Association of total, acylated and unacylated ghrelin with apolipoprotein $A 1$ and insulin concentrations in acromegalic patients
}

\author{
Hanna Komarowska1,A-D,F, Barbara Bromińska ${ }^{1, B, C, F}$, Nadia Sawicka-Gutaj] ${ }^{1}, C, D, F$, Magdalena Jaskula-Świtek ${ }^{1, B, F}$, \\ Ryszard Waśko ${ }^{1, A}$, Marek Ruchała ${ }^{1, E, F}$, Gabriel Bromiński2, ${ }^{2, F}$, Małgorzata Kotwicka ${ }^{3, A, E, F}$ \\ ${ }^{1}$ Department of Endocrinology, Metabolism and Internal Medicine, Poznan University of Medical Sciences, Poland \\ 2 Department of Urology and Urologic Oncology, Poznan University of Medical Sciences, Poland \\ ${ }^{3}$ Department of Cell Biology, Poznan University of Medical Sciences, Poland \\ A - research concept and design; $\mathrm{B}$ - collection and/or assembly of data; $\mathrm{C}$ - data analysis and interpretation; \\ $D$ - writing the article; $E$ - critical revision of the article; $F$ - final approval of the article
}

Address for correspondence

Hanna Komarowska

E-mail:hkomar@ump.edu.pl

Funding sources

This research was funded by the National Science Centre of Poland (grant No. NN 402 523 040).

Conflict of interest

None declared

Received on July 18,2018

Reviewed on August 14, 2018

Accepted on October 9, 2018

Published online on March 19, 2019

Cite as

Komarowska H, Bromińska B, Sawicka-Gutaj N, et al. Association of total, acylated and unacylated ghrelin with apolipoprotein A1 and insulin concentrations in acromegalic patients. Adv Clin Exp Med. 2019;28(6):789-795.

doi:10.17219/acem/97403

DOI

10.17219/acem/97403

Copyright

Copyright by Author(s)

This is an article distributed under the terms of the

Creative Commons Attribution Non-Commercial License

(http://creativecommons.org/licenses/by-nc-nd/4.0/)

\begin{abstract}
Background. Ghrelin is a hormone that occurs in acylated (AG) or unacylated (UG) form. Ghrelin strongly stimulates growth hormone (GH) secretion from anterior pituitary, as well as regulates the energy balance and various metabolic parameters. Increased consideration is given to UG, thought to be inactive.

Objectives. We aimed to evaluate the levels of total ghrelin, AG and UG in medically naive and treated patients with biochemically active acromegaly, with respect to variables of lipid and glucose metabolism.

Material and methods. We studied total ghrelin, AG and calculated UG levels in a group of 24 patients with active acromegaly and 15 healthy controls. Plasma levels of GH, insulin-like growth factor 1 (IGF-1), insulin, glucose, total cholesterol (TC), high-density lipoprotein (HDL) cholesterol and calculated low-density lipoprotein (LDL) cholesterol, triglycerides (TG), apolipoproteins A1 (AP0 A1), and B-100 (AP0 B-100) were measured.

Results. Patients with acromegaly revealed lower levels of total ghrelin than healthy controls. In pooled data of all subgroups, simple linear regression analysis revealed that total ghrelin concentration was significantly associated with APO A1 concentration ( $\beta=0.8087 ; p=0.0315$ ) and AG concentration was significantly associated with fasting insulin concentration ( $\beta=15.5183 ; p=0.011$ ). There was an inverse association between UG and the patients' age, and positive association between UG and APO A1.

Conclusions. Our results suggest that ghrelin may influence metabolic disturbances in acromegaly. It seems that the assessment of $A G$ and $U G$ is superior to total ghrelin measurement. Mechanisms regulating ghrelin acylation and function of each form need elucidation in order to improve diagnostics and treatment of metabolic disturbances, not only acromegaly.
\end{abstract}

Key words: ghrelin, acromegaly, apolipoprotein A-1, apolipoprotein B-100 


\section{Introduction}

Ghrelin is an endogenous ligand for the growth hormone secretagogue receptor (GHS-R). Its first discovered function was the stimulation of growth hormone $(\mathrm{GH})$ release from the anterior pituitary. This 28 aminoacid peptide was described and named by Kojima et al. in $1999 .{ }^{1}$ Post-translational modification-o-n-octanoylation at serine 3 enables binding with GHS-R1a receptor. This is essential for main biological functions of ghrelin: GH release stimulation, regulation of glucose and energy homeostasis. ${ }^{2}$ Ghrelin also controls lipid metabolism, both centrally and peripherally. It is the main modulator of hypothalamic lipid metabolism and stimulator of lipogenesis in white adipose tissue. ${ }^{3}$

Ghrelin occurs in acylated (AG) or unacylated (UG) form. Unacylated protein (80-90\% of ghrelin in bloodstream) until recently has been considered to be inactive. However, recent research suggests that both forms may have biological functions. They influence the cardiovascular system, adipogenesis and cell proliferation. The unacylated form regulates transport and metabolism of lipids in the human body, presumably through a different kind of receptor., ${ }^{4,5}$

Lipoproteins are particles with a central hydrophobic core containing cholesterol esters and triglycerides surrounded by an outer layer made out of free cholesterol, phospholipids and proteins (apolipoproteins). ${ }^{6}$ Among serum apolipoproteins, APO B100 and APO A1 are the most important. Increased concentrations of lipoproteins rich in APO B-100 (VLDL - very low density lipoprotein, VLDL remnants, IDL - intermediate density lipoprotein, LDL - low density lipoprotein, lipoprotein(a)) and decreased levels of those containing mostly APO A1 is pro-atherogenic and facilitates progression of atherosclerosis. ${ }^{7}$

Acromegaly is a rare, chronic illness characterized by increased secretion of $\mathrm{GH}$, most commonly by autonomous adenoma of the anterior pituitary. Rare underlying causes are ectopic $\mathrm{GH}$ releasing hormone $(\mathrm{GHRH})$ or $\mathrm{GH}$ production by neuroendocrine tumors. Men and women are affected with equal frequency. Typical symptoms are accompanied by systemic disturbances, mainly in the cardiovascular (cardiomyopathy, hypertension and premature atherosclerosis damaging brain and coronary arteries) and respiratory systems (obstructive sleep apnea). ${ }^{8}$

Growth hormone oversecretion is associated with metabolic consequences such as glucose intolerance, insulin resistance and dyslipidemia. Mortality in acromegaly is $2-3$ times higher than in the general population, mainly due to cardiovascular and respiratory diseases. ${ }^{9}$ First line treatment is transsphenoidal surgery, sometimes preceded by long-acting somatostatin analogs (SSAs) administration. ${ }^{10}$

While in $70 \%$ of cases acromegaly is associated with pituitary macroadenoma, ${ }^{11}$ most patients require additional treatment. For those with persistent disease following surgery, pharmacological treatment or/and radiotherapy is recommended. ${ }^{10}$
Metabolic complications in acromegalic patients, e.g., lipid profile disturbances, occur due to GH insulin-antagonistic effect. One of the functions of ghrelin is the regulation of glucose turnover and adipose tissue metabolism. ${ }^{12}$ Ghrelin might be involved in acromegaly pathogenesis. What is more, ghrelin may be associated with disturbances in lipid and glucose metabolism in acromegalic patients. ${ }^{13}$ Research concerning ghrelin in acromegaly is scarce and offers conflicting results. This study assesses total ghrelin, AG and UG in acromegalic patients. To our knowledge, the association between serum apolipoproteins and ghrelin has not been investigated before.

In this study we aimed to evaluate the levels of total ghrelin, AG and UG in medically naive and treated patients with biochemically active acromegaly with respect to variables of lipid and glucose metabolism.

\section{Material and methods}

\section{Study design and patients}

This was a case-control study. The study group consisted of 24 patients diagnosed with active acromegaly. The diagnosis of acromegaly was based on the lack of serum GH suppression to $<1 \mu \mathrm{g} / \mathrm{L}$ during a $75 \mathrm{~g}$ oral glucose tolerance test (OGTT), as well as the elevated serum insulin-like growth factor 1 (IGF-1) level. The criteria for disease control were GH suppression below $1 \mu \mathrm{g} / \mathrm{L}$ and normal IGF-1 level for age and sex, during long acting SSAs treatment. Exclusion criteria for the current study were remission of acromegaly, history or clinical or laboratory evidence of chronic disease including liver failure or renal failure, active cancer, and active infectious disease. Fifteen healthy volunteers served as controls. The physical examination of each subject was performed. Height, weight and systolic and diastolic blood pressure were measured in each patient. Blood samples were obtained after an overnight fasting.

All procedures performed in the study were in accordance with the ethical standards of the institutional research committee and with the 1964 Helsinki Declaration and its later amendments or comparable ethical standards. Informed consent was obtained from all individual participants included in the study.

\section{Methods}

Fasting serum levels of total ghrelin, AG, GH, IGF-1, total cholesterol, high-density lipoprotein (HDL), low-density lipoprotein (LDL), triglycerides (TG), apolipoprotein A-1 (APO A1), apolipoprotein B-100 (APO B-100), glucose, and insulin levels were evaluated. Hormonal and biochemical measurements were performed using the following methods: total ghrelin - RIA (Phoenix Pharmaceuticals, Burlingame, USA); AG - enzyme-linked immunosorbent assay (ELISA) assay kit (Sceti, Tokyo, Japan); UG was calculated 
by subtracting AG from total ghrelin. Growth hormone and IGF-1 - IRMA and RIA (Biosource Europe, Nivelles, Belgium); insulin and glucose - electrochemiluminescence (ECL) (Roche Diagnostics, Risch-Rotkreuz, Switzerland); total cholesterol - enzymatic colorimetric method, HDL cholesterol - homogenic colorimetric enzymatic method, TG - enzymatic colorimetric method with glycerophosphate oxidase and 4-aminophenazon. The LDL cholesterol was calculated on the basis of the concentrations of total and HDL cholesterol. Apolipoproteins A1 and B-100 were assessed using ELISA assay kit (AssayPro, St. Charles, USA). Insulin sensitivity was estimated with homeostasis model assessment (HOMA) index. The following formula was used: $\mathrm{HOMA}=(\mathrm{FG} * \mathrm{FI}) / 22.5$.

\section{Statistical analysis}

Statistical analysis was performed with MedCalc Statistical Software v. 16.8.4 (MedCalc Software bvba, Ostend, Belgium; https://www.medcalc.org; 2016). Normality was analyzed with the D'Agostino-Pearson test. When the data did not follow normal distribution, comparisons between 3 groups were performed with the Kruskal-Wallis test. Oneway analysis of variance (ANOVA) was used to compare normally distributed parameters between all groups. A $\chi^{2}$ test was used to compare discrete variables. Simple regression analysis was used to test for the relationships between them. Before inclusion to this statistical analysis, non-normally distributed parameters were logarithmically transformed. P-value $<0.05$ was considered statistically significant.

\section{Results}

In the study group, 8 patients were newly diagnosed and 16 patients received SSAs (9 lanreotide, 7 octreotide). Fourteen patients underwent transsphenoidal resection of GHsecreting adenoma. The remaining 2 patients on SSAs had cardiological contraindication for surgical treatment. Twelve patients treated with long acting SSAs did not meet the criteria for acromegaly control and 4 patients had controlled disease. Patients in the study and the control group did not differ according to sex, age and concomitant diseases. Clinical characteristics of both groups are presented in Table 1. The comparison of laboratory parameters between the study and the control groups is shown in Table 2. Patients with acromegaly had lower levels of total ghrelin than healthy controls (Fig. 1). Other analyzed parameters did not differ between both groups (Table 2). In pooled data of all subgroups, simple linear regression analysis revealed that the total ghrelin concentration was significantly associated with APO A1 concentration $(\beta=0.8087$; $\mathrm{p}=0.0315$ ) (Fig. 2), and AG concentration was significantly associated with fasting insulin concentration $(\beta=15.5183$; $\mathrm{p}=0.011$ ). There was no association between total ghrelin or AG and age, BMI, fasting glucose, TC, HDL, LDL, TG, APO A1 nor APO B levels, IGF-1, and GH (Table 3). There was an inverse association between UG and patients' age, and positive association between UG and APO A1. When acromegalic patients were analyzed separately, total ghrelin and UG were positively associated with APO A1 $(\beta=1.2126 ; p=0.0003$ and $\beta=1.6533 ; p=0.0074$, respectively). There was also a positive relationship between AG and insulin concentrations $(\beta=14.59 ; \mathrm{p}=0.0377)$.

\section{Discussion}

Foregoing studies concerning the role of ghrelin in acromegaly gave conflicting results. ${ }^{14-18}$ Usually, the discrepancies were explained by small, heterogeneous studied groups, differences in treatment regimens and difficulties in assessing AG levels. ${ }^{19,20}$ Lack of correlation between ghrelin, GH, IGF-1, and BMI in our research might be explained identically. In the majority of published studies, only AG or/and total ghrelin was assessed. Recently,

Table 1. Clinical characteristics of the study and the control group

\begin{tabular}{|c|c|c|c|c|}
\hline Variable & $\begin{array}{l}\text { Newly diagnosed } \\
\text { acromegalic patients } \\
(\mathrm{n}=8)\end{array}$ & $\begin{array}{l}\text { Acromegalic patients } \\
\text { treated with SSAs } \\
\qquad(\mathrm{n}=16)\end{array}$ & $\begin{array}{l}\text { Controls } \\
(n=15)\end{array}$ & $\mathrm{p}$-value \\
\hline $\begin{array}{l}\text { Age [years] } \\
\mathrm{Me}(\mathrm{IQR})\end{array}$ & $\begin{array}{c}55 \\
(53-62)\end{array}$ & $\begin{array}{c}52 \\
(44.0-56.5)\end{array}$ & $\begin{array}{c}52 \\
(44-58)\end{array}$ & 0.48 \\
\hline Sex & $\begin{array}{l}F: 4 \\
M: 4\end{array}$ & $\begin{array}{l}F: 6 \\
M: 10\end{array}$ & $\begin{array}{l}F: 8 \\
M: 7\end{array}$ & 0.67 \\
\hline $\begin{array}{l}\text { Weight [kg] } \\
\text { Me (IQR) }\end{array}$ & $\begin{array}{c}81.5 \\
(64.5-105.0)\end{array}$ & $\begin{array}{c}93.5 \\
(79.5-103.1)\end{array}$ & $\begin{array}{c}89 \\
(79.0-102.7)\end{array}$ & 0.54 \\
\hline $\begin{array}{l}\text { Height [m] } \\
\text { Me (IQR) }\end{array}$ & $\begin{array}{c}1.66 \\
(1.55-1.79)\end{array}$ & $\begin{array}{c}1.74 \\
(1.63-1.96)\end{array}$ & $\begin{array}{c}1.78 \\
(1.62-1.79)\end{array}$ & 0.29 \\
\hline $\begin{array}{l}\text { BMI }\left[\mathrm{kg} / \mathrm{m}^{2}\right] \\
\mathrm{Me}(\mathrm{IQR})\end{array}$ & $\begin{array}{c}30.6 \\
(25.6-31.6)\end{array}$ & $\begin{array}{c}29.5 \\
(26.0-31.2)\end{array}$ & $\begin{array}{c}30.8 \\
(27.2-32.6)\end{array}$ & 0.70 \\
\hline Controlled hypertension, n [\%] & $6(75)$ & $8(50)$ & $7(46.7)$ & 0.40 \\
\hline Diabetes mellitus, n [\%] & $2(25)$ & $1(6.25)$ & $4(26.7)$ & 0.25 \\
\hline
\end{tabular}

Me - median; F - females; M - males; IQR - interquartile range; SD - standard deviation; SSAs - long acting somatostatin analogs. 


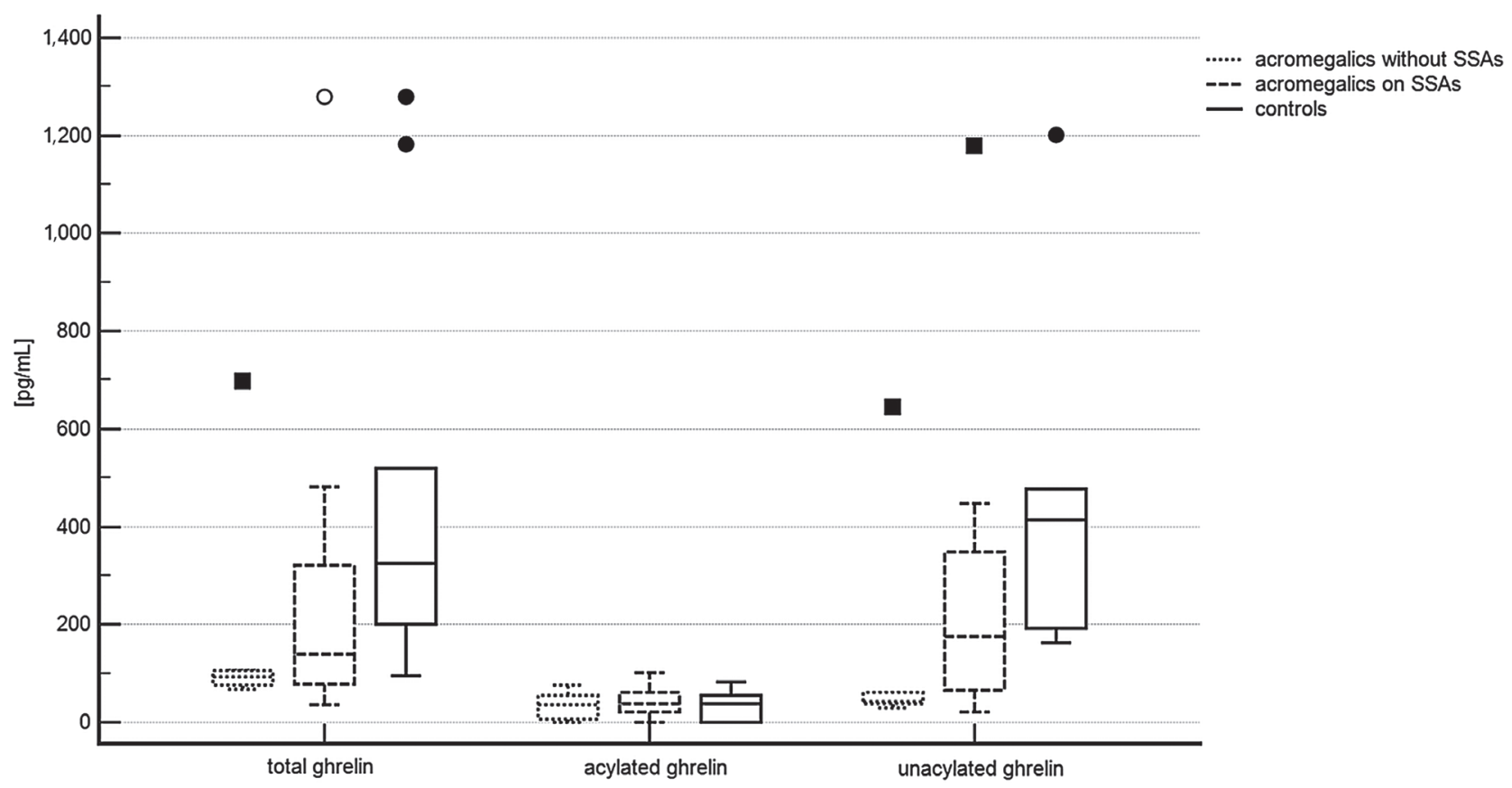

Fig. 1. Comparison of total ghrelin levels between the study and the control groups. The central box represents the values from the lower to upper quartile $\left(25^{\text {th }}\right.$ to $75^{\text {th }}$ percentile). The middle line represents the median. Whiskers extend to a multiple of $\times 1.5$ the distance of the upper and lower quartile, respectively. Outliers are any values beyond the whiskers

Table 2. Laboratory parameters of the study and the control groups

\begin{tabular}{|c|c|c|c|c|}
\hline Variable & $\begin{array}{l}\text { Newly diagnosed } \\
\text { acromegalic patients } \\
\qquad(\mathrm{n}=8)\end{array}$ & $\begin{array}{l}\text { Acromegalic patients } \\
\text { treated with SSAs } \\
\qquad(\mathrm{n}=16)\end{array}$ & $\begin{array}{l}\text { Controls } \\
(n=15)\end{array}$ & $p$-value \\
\hline $\begin{array}{l}\text { Total ghrelin }[\mathrm{pg} / \mathrm{mL}] \\
\text { Me (IQR) }\end{array}$ & $\begin{array}{c}91.94^{*} \\
(75.15-105.80)\end{array}$ & $\begin{array}{c}140.27 \wedge \\
(79.05-320.14)\end{array}$ & $\begin{array}{c}324.84^{* \wedge} \\
(201.06-519.58)\end{array}$ & 0.0469 \\
\hline $\begin{array}{l}\text { AG }[\mathrm{fmol} / \mathrm{mL}] \\
\mathrm{Me}(\mathrm{IQR})\end{array}$ & $\begin{array}{c}15.65 \\
(5.63-16.40)\end{array}$ & $\begin{array}{c}12.5 \\
(9.55-20.20)\end{array}$ & $\begin{array}{c}15.58 \\
(11.81-21.52)\end{array}$ & 0.6677 \\
\hline $\begin{array}{l}\text { UG }[\mathrm{pg} / \mathrm{mL}] \\
\operatorname{Me}(\mathrm{IQR})\end{array}$ & $\begin{array}{c}42.7^{*} \\
(37.6-61.2)\end{array}$ & $\begin{array}{c}174.8 \\
(65.7-349.3)\end{array}$ & $\begin{array}{c}414.8^{*} \\
(192.3-477.0)\end{array}$ & 0.0365 \\
\hline $\begin{array}{l}\text { APO A1 }[\mu \mathrm{g} / \mathrm{mL}] \\
\text { Me (IQR) }\end{array}$ & $\begin{array}{c}2032.5 \\
(1189.5-4185.0)\end{array}$ & $\begin{array}{c}2628 \\
(1881.50-3729.75)\end{array}$ & $\begin{array}{c}1470 \\
(1292-2993)\end{array}$ & 0.2365 \\
\hline $\begin{array}{l}\text { APO B }[\mu \mathrm{g} / \mathrm{mL}] \\
\mathrm{Me}(\mathrm{IQR})\end{array}$ & $\begin{array}{c}2208.5 \\
(1909.5-2613.5)\end{array}$ & $\begin{array}{c}2368 \\
(2072.0-2528.5)\end{array}$ & $\begin{array}{c}2207 \\
(1722.5-2517.5)\end{array}$ & 0.9132 \\
\hline $\begin{array}{l}\text { Fasting glucose }[\mathrm{mg} / \mathrm{dL}] \\
\text { Me (IQR) }\end{array}$ & $\begin{array}{c}102 \\
(97-119)\end{array}$ & $\begin{array}{c}96 \\
(102.5-120.0)\end{array}$ & $\begin{array}{c}90 \\
(89.0-98.7)\end{array}$ & 0.1492 \\
\hline $\begin{array}{l}\text { Fasting insulin }[\mu \mathrm{u} / \mathrm{mL}] \\
\mathrm{Me}(\mathrm{IQR})\end{array}$ & $\begin{array}{c}8.68 \\
(7.67-13.29)\end{array}$ & $\begin{array}{c}7.81 \\
(5.01-11.73)\end{array}$ & $\begin{array}{c}9.62 \\
(5.89-25.74)\end{array}$ & 0.7633 \\
\hline $\begin{array}{l}\text { TC }[\mathrm{mg} / \mathrm{dL}] \\
\mathrm{Me}(\mathrm{IQR})\end{array}$ & $\begin{array}{c}198 \\
(182.25-260.00)\end{array}$ & $\begin{array}{c}198 \\
(188-220)\end{array}$ & $\begin{array}{c}216 \\
(173.5-243.0)\end{array}$ & 0.9280 \\
\hline $\begin{array}{l}\mathrm{LDL}[\mathrm{mg} / \mathrm{dL}] \\
\mathrm{Me}(\mathrm{IQR})\end{array}$ & $\begin{array}{c}130 \\
(111.85-173.05)\end{array}$ & $\begin{array}{c}116 \\
(97.60-140.85)\end{array}$ & $\begin{array}{c}125.7 \\
(88.0-171.2)\end{array}$ & 0.6679 \\
\hline $\begin{array}{l}\mathrm{HDL}[\mathrm{mg} / \mathrm{dL}] \\
\mathrm{Me}(\mathrm{IQR})\end{array}$ & $\begin{array}{c}48 \\
(43.75-66.00)\end{array}$ & $\begin{array}{c}56 \\
(49-64)\end{array}$ & $\begin{array}{c}42 \\
(37.00-66.75)\end{array}$ & 0.3032 \\
\hline $\begin{array}{l}\text { TG }[\mathrm{mg} / \mathrm{dL}] \\
\text { Me (IQR) }\end{array}$ & $\begin{array}{c}121 \\
(104.25-130.25)\end{array}$ & $\begin{array}{c}122.5 \\
(91-171)\end{array}$ & $\begin{array}{c}163.5 \\
(94-255)\end{array}$ & 0.3346 \\
\hline $\begin{array}{l}\mathrm{GH}[\mathrm{ng} / \mathrm{mL}] \\
\mathrm{Me}(\mathrm{IQR})\end{array}$ & $\begin{array}{c}5.455^{* \wedge} \\
(2.94-31.47)\end{array}$ & $\begin{array}{c}2.02^{\wedge} \\
(1.26-4.68)\end{array}$ & $\begin{array}{c}1.3^{*} \\
(0.77-1.83)\end{array}$ & 0.0354 \\
\hline $\begin{array}{l}\text { IGF-1 [ng/mL] } \\
\text { Me (IQR) }\end{array}$ & $\begin{array}{c}1081^{*} \\
(480-1297)\end{array}$ & $\begin{array}{c}440 \\
(328.0-927.5)\end{array}$ & $\begin{array}{c}202^{*} \\
(125-279)\end{array}$ & 0.0359 \\
\hline
\end{tabular}

Me - median; IQR - interquartile range; AG - acylated ghrelin; UG - unacylated ghrelin; APO A1 - apolipoprotein A1; APO B - apolipoprotein B; TC - total cholesterol; LDL - low-density lipoprotein; HDL - high-density lipoprotein; TG - triglycerides; GH - growth hormone; IGF-1 - insulin-like growth factor 1; SSAs - long acting somatostatin analogs; data followed with the same markers (* or $\wedge$ ) differed significantly; values in bold mean that the relationships were statistically significant. 
Table 3. Simple linear regression analysis using total ghrelin and AG serum concentration as dependent variables in pooled data of study and control groups

\begin{tabular}{|c|c|c|c|c|c|c|}
\hline \multirow{2}{*}{ Variable } & \multicolumn{2}{|c|}{ Total ghrelin concentration (log) } & \multicolumn{2}{|c|}{ AG concentration } & \multicolumn{2}{|c|}{ UG concentration (log) } \\
\hline & $\beta$ & $\mathrm{p}$-value & $\beta$ & $p$-value & $\beta$ & $\mathrm{p}$-value \\
\hline Age (log) & -0.9718 & 0.0744 & 1.5235 & 0.8764 & -1.4111 & 0.0498 \\
\hline $\mathrm{BMI}$ & 0.01939 & 0.3490 & -0.4168 & 0.2795 & 0.0399 & 0.1756 \\
\hline APO A1 (log) & 0.8087 & 0.0315 & -9.4672 & 0.1356 & 1.1473 & 0.0370 \\
\hline APOB & 0.0001 & 0.6141 & 0.0040 & 0.1503 & 0.0001 & 0.4524 \\
\hline Fasting glucose (log) & -0.0393 & 0.9575 & -5.4848 & 0.6560 & -0.0393 & 0.9579 \\
\hline Fasting insulin (log) & 0.2505 & 0.5112 & 15.5183 & 0.0110 & 0.2597 & 0.6248 \\
\hline HOMA (log) & 0.3271 & 0.4589 & 20.9797 & 0.0100 & 0.6632 & 0.3345 \\
\hline TC & 0.0021 & 0.3207 & -0.0390 & 0.3676 & 0.0036 & 0.2465 \\
\hline LDL & 0.0018 & 0.4574 & -0.0238 & 0.6140 & 0.0018 & 0.4574 \\
\hline $\mathrm{HDL}$ & -0.0015 & 0.7920 & -0.1312 & 0.2014 & -0.0057 & 0.4356 \\
\hline TG (log) & 0.3342 & 0.4961 & 4.1919 & 0.6946 & 0.3342 & 0.4961 \\
\hline GH (log) & -0.1430 & 0.3425 & 0.2759 & 0.9149 & -0.2851 & 0.1436 \\
\hline IGF-1 & -0.0001 & 0.8076 & 0.0019 & 0.5536 & -0.0002 & 0.3656 \\
\hline
\end{tabular}

AG - acylated ghrelin; UG - unacylated ghrelin; BMI - body mass index; APO A1 - apolipoprotein A1; APO B - apolipoprotein B; HOMA - homeostatic model assessment; TC - total cholesterol; LDL - low-density lipoprotein; HDL - high-density lipoprotein; TG - triglycerides; GH - growth hormone; IGF-1 - insulinlike growth factor 1 ; values in bold mean that the relationships were statistically significant.

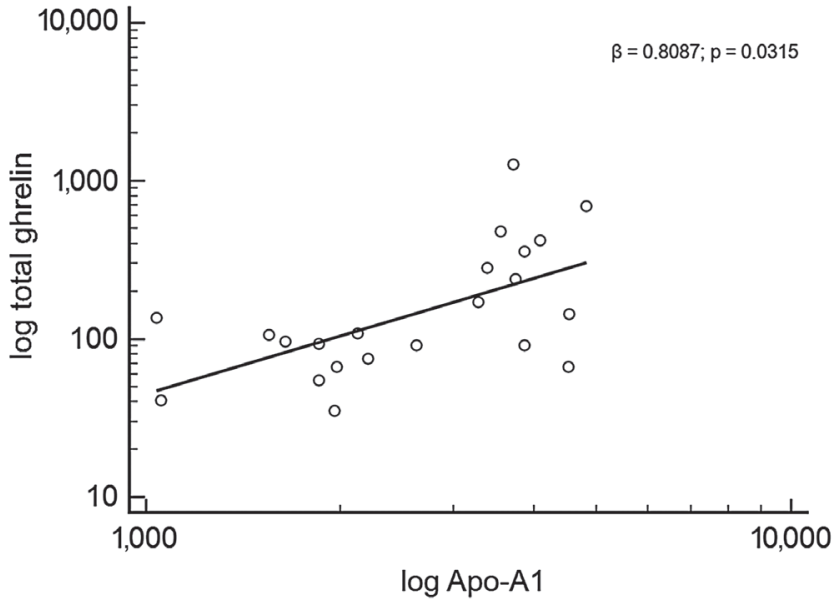

Fig. 2. Association between total ghrelin serum level and APO A1. Data was log-transformed to achieve normal distribution

attention has been focused on UG and AG. Only AG binds with GHR-R, which is why it is called "active". Thus, it was estimated that UG does not have any biological role. However, there is growing evidence against this thesis. The unacylated form, among other functions, positively influences glycemic control in diabetes and exerts regulatory effects on cardiovascular system. ${ }^{21-24}$

We assessed total ghrelin, AG and UG serum concentration, and found lowered total ghrelin levels in acromegalic patients when compared to healthy controls, which is in line with other studies ${ }^{15-17}$ (Table 2). In contrast to other authors, the observed difference resulted from low UG concentration and it was not associated with a decrease in AG. A decrease in UG concentration was found in medically naive acromegalic patients, while the AG level was similar regardless of the activity of acromegaly. Cederberg et al. stressed the unfavorable effect of increased AG to the UG ratio leading to diabetes type 2 , obesity and hyperphagia. ${ }^{25}$ Muhammad et al. suggested the superiority of a ghrelin ratio assessment in comparison with a sole total ghrelin evaluation. ${ }^{26}$ Previously, we have noticed that the mean concentrations of total ghrelin and AG were significantly higher in acromegalic patients presented with hypercholesterolemia compared with patients with normocholesterolemia. ${ }^{13}$ The UG might inhibit the diabetogenic and atherogenic effects of AG. Thus, a decrease in UG might contribute to insulin resistance, diabetes and atherogenic lipid profile observed in acromegalic patients. Since SSA therapy improves glycemic control and lipid profile, it might explain the increase of serum UG concentration in treated acromegalic patients. Additionally, in our study UG correlated with the patient's age. Its concentration decreases in older people. We could speculate that insulin resistance and atherogenic lipid profile, very common in elderly patients, are associated with disturbances in ghrelin ratio.

Hyperinsulinemia is a very common metabolic disturbance in active acromegaly. Growth hormone normalization after transsphenoidal resection of somatotroph adenoma causes insulin sensitivity improvement. ${ }^{15,27}$ Freda et al. suggested that it might be connected with an increase in ghrelin. ${ }^{15}$ Additionally, Cappiello et al. ${ }^{28}$ confirmed a negative correlation between insulin and ghrelin. In both studies, only total ghrelin was assessed. While most abundant ghrelin fraction in a bloodstream is UG (80-90\%) this correlation probably refers to UG. Moreover, in research by Barazzoni et al., HOMA index correlated negatively with total ghrelin and UG. ${ }^{29}$ Acylated form probably exerts contraindicatory effects, inducing insulin resistance. In our research, we concluded that AG is positively correlated with insulin. Moreover, when AG 
levels rise, HOMA index values increase in both acromegalic patients and in the whole studied group. This might confirm the negative impact of AG on insulin metabolism.

There are ongoing studies on ghrelin-O-acyltransferase enzyme (GOAT), which acylates ghrelin. GOAT was identified in 2008 as a member of membrane bound O-acyl transferase (MBOAT) family, a group of integral membrane proteins involved in lipid-biosynthetic and lipidsignaling reactions. ${ }^{30,31}$ The expression of GOAT is similar to that of ghrelin. ${ }^{32}$ It is regulated by energy balance, metabolic status and hormones, such as leptin, somatostatin and ghrelin. Unacylated ghrelin does not seem to influence GOAT expression. ${ }^{31}$ Most of the recently conducted studies have been performed on animal models. ${ }^{33,34}$ Kouno et al. discovered that GOAT knockout mice consumed less amount of food, gained weight slower, and had better glucose metabolism and insulin sensitivity than wildtype littermates. ${ }^{33}$ Moreover, GOAT inhibitors increase insulin secretion, enhance peripheral insulin sensitivity, and thereby prevent diabetes and diet-induced obesity. ${ }^{35,36}$ Only a few studies concerning GOAT in human have been published. ${ }^{36,37}$ Hopkins et al. showed that UG is activated by GOAT located in the target cell. ${ }^{38}$ This suggests that UG is subjected to target cell-mediated activation, a novel mechanism for manipulating hormone activity. To our knowledge, there are no studies concerning GOAT expression in acromegaly. In the light of previous research and our results, the variation in ghrelin ratio may be one of the factors determining the development of metabolic disturbances in acromegaly. Therefore, further studies concerning GOAT and ghrelin acylation blockade in acromegaly would be of great value. In the future, drugs inhibiting GOAT could possibly be useful to prevent metabolic abnormalities in acromegalic patients.

Unacylated ghrelin may influence adipose tissue metabolism. Ghrelin inhibits lipolysis and stimulates adipogenesis by direct influence on adipocytes and preadipocytes through unknown receptor. ${ }^{24}$ Ghrelin in serum interacts with lipoproteins. ${ }^{39,40}$ Heksarelin after binding with CD26 receptor exerts anti-atherogenic effect. Low-density lipoprotein is a ligand for CD26 receptor. ${ }^{40}$ It is possible that UG acts similarly to heksarelin. Outer layer of lipoproteins is made out of apolipoproteins, which function as a ligand for receptors. The receptor for UG is unknown. Perhaps UG is biologically active only after binding with lipoproteins and in this form is recognized by the receptor. In our study, we found a correlation between UG and APO A1. It might be suggested that ghrelin influences lipid metabolism through this mechanism.

To sum up, our results may suggest that ghrelin influences metabolic disturbances in acromegaly. It seems that the assessment of AG and UG is superior to total ghrelin measurement. However, the regulation of ghrelin secretion in acromegaly is complex, which might possibly explain the unequivocal results of studies on ghrelin in acromegaly. Even if there is a feedback loop between ghrelin, GH and/or IGF-1, the secretion of ghrelin has to be modulated by other factors. Mechanisms regulating ghrelin acylation and the function of each form are complex but need elucidation in order to improve diagnostics and the treatment of metabolic disturbances, not only in acromegaly. Further studies should answer if GOAT evaluation and its pharmacological blockade may be useful in the prevention of metabolic complications related to ghrelin disturbances.

The main limitation of the study is the small sample size, but it is one of the firsts papers assessing both total ghrelin, AG and UG in acromegalic patients and first paper about the association between serum apolipoproteins and ghrelin. Our results seem to be interesting and worth further analysis.

\section{References}

1. Kojima M, Hosoda H, Date Y, Nakazato M, Matsuo H, Kangawa K. Ghrelin is a growth-hormone-releasing acylated peptide from stomach. Nature. 1999;402(6762):656-660. doi:10.1038/45230

2. Kojima M, Kangawa K. Ghrelin: Structure and function. Physiol Rev. 2005;85(2):495-522. doi:10.1152/physrev.00012.2004

3. Varela L, Vázquez MJ, Cordido F, et al. Ghrelin and lipid metabolism: Key partners in energy balance. J Mol Endocrinol. 2011;46(2):R43-63. doi:10.1677/JME-10-0068

4. Harisseh R, Pillot B, Gharib A, et al. Unacylated ghrelin analog prevents myocardial reperfusion injury independently of permeability transition pore. Basic Res Cardiol. 2017;112(1):4. doi:10.1007/s00395016-0595-9

5. Au CC, Furness JB, Brown KA. Ghrelin and breast cancer: Emerging roles in obesity, estrogen regulation, and cancer. Front Oncol. 2016; 6:265. doi:10.3389/fonc.2016.00265

6. Feingold KR, Grunfeld C. Introduction to lipids and lipoproteins. In: De Groot LJ, Chrousos G, Dungan K, et al., eds. Endotext. South Dartmouth, MA: MDText.com, Inc.; 2000. http://www.ncbi.nIm.nih.gov/ books/NBK305896/. Accessed June 12, 2018.

7. Manjunath CN, Rawal JR, Irani PM, Madhu K. Atherogenic dyslipidemia. Indian J EndocrinolMetab. 2013;17(6):969-976. doi:10.4103/22308210.122600

8. Pivonello R, Auriemma RS, Grasso LFS, et al. Complications of acromegaly: Cardiovascular, respiratory and metabolic comorbidities. Pituitary. 2017;20(1):46-62. doi:10.1007/s11102-017-0797-7

9. Găloiu S, Poiană C. Current therapies and mortality in acromegaly. J Med Life. 2015;8(4):411-415.

10. Katznelson L, Laws ER, Melmed S, et al. Acromegaly: An endocrine society clinical practice guideline. J Clin Endocrinol Metab. 2014;99(11): 3933-3951. doi:10.1210/jc.2014-2700

11. Miranda-Rius J, Brunet-LLobet L, Lahor-Soler E, et al. GH-secreting pituitary macroadenoma (acromegaly) associated with progressive dental malocclusion and refractory CPAP treatment. Head Face Med. 2017;13(1):7. doi:10.1186/s13005-017-0140-6

12. Leite-Moreira AF, Soares J-B. Physiological, pathological and potential therapeutic roles of ghrelin. Drug Discov Today. 2007;12(7-8): 276-288. doi:10.1016/j.drudis.2007.02.009

13. Jaskula M, Wasko R, Komarowska H, Dziubandowska A, Sowinski J. Serum ghrelin levels and disturbances of the lipid profile in patients with acromegaly. Neuro Endocrinol Lett. 2009;30(2):245-255.

14. Jarkovská Z, Rosická M, Marek J, et al. Plasma levels of total and active ghrelin in acromegaly and growth hormone deficiency. Physiol Res. 2006;55(2):175-181.

15. Freda PU, Reyes CM, Conwell IM, Sundeen RE, Wardlaw SL. Serum ghrelin levels in acromegaly: Effects of surgical and long-acting octreotide therapy. J Clin Endocrinol Metab. 2003;88(5):2037-2044. doi:10.1210/jc.2002-021683

16. Kawamata T, Inui A, Hosoda H, Kangawa K, Hori T. Perioperative plasma active and total ghrelin levels are reduced in acromegaly when compared with in nonfunctioning pituitary tumors even after normalization of serum GH. Clin Endocrinol (Oxf). 2007;67(1):140-144. doi:10.1111/j.1365-2265.2007.02851.x 
17. Reyes-Vidal C, Fernandez JC, Bruce JN, et al. Prospective study of surgical treatment of acromegaly: Effects on ghrelin, weight, adiposity, and markers of CV risk. J Clin Endocrinol Metab. 2014;99(11): 4124-4132. doi:10.1210/jc.2014-2259

18. Wasko R, Jaskula M, Komarowska H, Zamyslowska H, Sowinski J, Waligorska-Stachura J. Ghrelin concentrations in acromegalic patients in relation to the administered therapy. Neuro Endocrinol Lett. 2006;27(1-2):162-168.

19. Delhanty PJD, Huisman M, Julien M, et al. The acylated (AG) to unacylated (UAG) ghrelin ratio in esterase inhibitor-treated blood is higher than previously described. Clin Endocrinol (Oxf). 2015;82(1):142-146. doi:10.1111/cen.12489

20. Kosowicz J, Baumann-Antczak A, Ruchała M, Gryczyńska M, Gurgul E, Sowiński J. Thyroid hormones affect plasma ghrelin and obestatin levels. Horm Metab Res. 2011;43(2):121-125. doi:10.1055/s-0030-1269853

21. Özcan B, Neggers SJCMM, Miller AR, et al. Does des-acyl ghrelin improve glycemic control in obese diabetic subjects by decreasing acylated ghrelin levels? Eur J Endocrinol. 2014;170(6):799-807. doi:10. 1530/EJE-13-0347

22. Delhanty PJ, Neggers SJ, van der Lely AJ. Des-acyl ghrelin: A metabolically active peptide. Endocr Dev. 2013;25:112-121. doi:10.1159/ 000346059

23. Kleinz MJ, Maguire JJ, Skepper JN, Davenport AP. Functional and immunocytochemical evidence for a role of ghrelin and des-octanoyl ghrelin in the regulation of vascular tone in man. Cardiovasc Res. 2006;69(1):227-235. doi:10.1016/j.cardiores.2005.09.001

24. Thompson NM, Gill DAS, Davies R, et al. Ghrelin and des-octanoyl ghrelin promote adipogenesis directly in vivo by a mechanism independent of the type 1a growth hormone secretagogue receptor. Endocrinology. 2004;145(1):234-242. doi:10.1210/en.2003-0899

25. Cederberg H, Rajala U, Koivisto V-M, et al. Unacylated ghrelin is associated with changes in body composition and body fat distribution during long-term exercise intervention. Eur J Endocrinol. 2011;165(2): 243-248. doi:10.1530/EJE-11-0334

26. Muhammad A, Delhanty PJD, Huisman M, Visser JA, Jan van der Lelij A, Neggers SJCMM. The acylated/unacylated ghrelin ratio is similar in patients with acromegaly during different treatment regimens. J Clin Endocrinol Metab. 2017;102(7):2425-2432. doi:10.1210/jc.201700147

27. Miya A, Nakamura A, Miyoshi H, et al. Glucose tolerance is improved following surgery for silent somatotroph adenoma. International Journal of Diabetes and Clinical Research. 2015;2:6-12.

28. Cappiello V, Ronchi C, Morpurgo PS, et al. Circulating ghrelin levels in basal conditions and during glucose tolerance test in acromegalic patients. Eur J Endocrinol. 2002;147(2):189-194.
29. Barazzoni R, Gortan Cappellari G, Semolic A, et al. Plasma total and unacylated ghrelin predict 5-year changes in insulin resistance. Clin Nutr. 2016;35(5):1168-1173. doi:10.1016/j.clnu.2015.10.002

30. González CR, Vázquez MJ, López M, Diéguez C. Influence of chronic undernutrition and leptin on GOAT mRNA levels in rat stomach mucosa. J Mol Endocrinol. 2008;41(6):415-421. doi:10.1677/JME-080102

31. Khatib MN, Gaidhane S, Gaidhane AM, Simkhada P, Zahiruddin QS. Ghrelin O acyl transferase (GOAT) as a novel metabolic regulatory enzyme. J Clin Diagn Res. 2015;9(2):LE01-05. doi:10.7860/JCDR/2015/ 9787.5514

32. Lim CT, Kola B, Grossman A, Korbonits M. The expression of ghrelin O-acyltransferase (GOAT) in human tissues. Endocr J. 2011;58(8): 707-710.

33. Kouno T, Akiyama N, Fujieda K, et al. Reduced intake of carbohydrate prevents the development of obesity and impaired glucose metabolism in ghrelin O-acyltransferase knockout mice. Peptides. 2016;86:145-152. doi:10.1016/j.peptides.2016.11.003

34. Barnett BP, Hwang Y, Taylor MS, et al. Glucose and weight control in mice with a designed ghrelin O-acyltransferase inhibitor. Science. 2010;330(6011):1689-1692. doi:10.1126/science.1196154

35. Teuffel $P$, Wang $L$, Prinz $P$, et al. Treatment with the ghrelin-O-acyltransferase (GOAT) inhibitor GO-CoA-Tat reduces food intake by reducing meal frequency in rats. J Physiol Pharmacol. 2015;66(4):493-503.

36. Ritze Y, Schollenberger A, Hamze Sinno M, et al. Gastric ghrelin, GOAT, leptin, and leptinR expression as well as peripheral serotonin are dysregulated in humans with obesity. Neurogastroenterol Motil. 2016;28(6):806-815. doi:10.1111/nmo.12773

37. Mihalache $L$, Gherasim A, Niță $O$, et al. Effects of ghrelin in energy balance and body weight homeostasis. Hormones (Athens). 2016;15(2): 186-196. doi:10.14310/horm.2002.1672

38. Hopkins AL, Nelson TAS, Guschina IA, et al. Unacylated ghrelin promotes adipogenesis in rodent bone marrow via ghrelin $\mathrm{O}$-acyl transferase and GHS-R1a activity: Evidence for target cell-induced acylation. Sci Rep. 2017;7:45541. doi:10.1038/srep45541

39. De Vriese C, Hacquebard M, Gregoire F, Carpentier Y, Delporte C. Ghrelin interacts with human plasma lipoproteins. Endocrinology. 2007;148(5):2355-2362. doi:10.1210/en.2006-1281

40. Purnell JQ, Weigle DS, Breen P, Cummings DE. Ghrelin levels correlate with insulin levels, insulin resistance, and high-density lipoprotein cholesterol, but not with gender, menopausal status, or cortisol levels in humans. J Clin Endocrinol Metab. 2003;88(12):5747-5752. doi:10.1210/jc.2003-030513 